\title{
An Empirical Study on Indonesian English-Curriculum Changes: Opportunities and Constraints in an Underdeveloped Region
}

\author{
Agus Riadi \\ Politeknik Tonggak Equator, Indonesia
}

Abstract: Ever since Indonesia adopted English as its foreign language in 1945 to be taught in schools, some changes have been made to achieve the national goal of learning the language. These changes were made following the teaching methodologies evolution around the world and later implied in the Indonesian English-curriculum. As the consequence of the implementation, the executor of this curriculum - teachers, in this regard - had to undergo some adjustments regardless of in which region they were teaching. The disparity of the curriculum properties (teacher training, textbooks, etc.) distribution was quite evident in the majority of areas in Indonesia. Therefore, this article examines several opportunities and constraints aimed to provide better insights from the rural-area teachers concerning the curriculum implementation. This research used historical and documentary research in the context of literature on curriculum and teachers' perception towards some curriculum renewal. The article concludes that despite having a number of changes, the stakeholder appears to fail in addressing the primary need of and providing some adequate assistance for the teachers in underdeveloped regions in readjusting to the change, resulting in the disproportion and disparity compared to those who teach in developed cities.

Keywords: English-curriculum, rural areas, teachers

\section{INTRODUCTION}

The importance of English language acquisition was acknowledged in Indonesia shortly after its independence in 1945 (Jazadi, 2000; Lamb \& Coleman, 2008). As in other South-East Asian countries, English is perceived to be a key factor ' $[\mathrm{t}] \mathrm{o}$ help our young people succeed in life and find greater personal fulfillment' through 'effective interaction in different cultural environments' (Nunan, 2003, p. 598). Even though Indonesia still considers English as a foreign language (Jazadi, 2000), the influence of English is evident across the country. This is particularly apparent in urban areas, where the use of English is mainly employed for communicative purposes (e.g. job interview) and business. Taking as an example the area of business advertisements, numerous products are also named and promoted in English. For example, as noted in one of Indonesia's daily newspapers, 'Kompas', there is a tendency for novels to be titled in English even 
though they are written in Bahasa (Lamb \& Coleman, 2008). Meanwhile, as English has penetrated the educational system, its effects are also reflected in Indonesian curriculum. One of these effects has been explored by Baso (2014), and shows how the influence of English affected the Indonesian universities curriculum in the East Borneo. She mentions that the content of the curriculum in tertiary level supposedly included TOEFL programme which also combined with English for Specific Programme to meet the demand of multi-national companies of their employees to acquire certain level of English. However, her study found that in practice, none of the universities in East Borneo was providing these programmes within their curriculum.

While the decentralisation of power - and subsequent urgency of regional autonomy was emphasised (Bjork, 2004; Huda, 2016) - began in 1998, there are still disparities as to how each region perceives policies from the central government. Huda maintains that this is the result of: (1) misconception from regional bodies in taking over the new responsibilities; (2) the attitude of central authorities; and (3) different perceptions on how to view the goal of decentralisation itself. A study by Lamb and Coleman (2008) examining two provinces in Indonesia reveals that one of the main aspects that distinguishes rural and urban areas in the educational context is in terms of tuition-fee policy. They say that in rural areas, there is a tendency for people in poor communities not to send their children to school, despite the fact that state schools are supposed to be free of charge. This is because those schools still require students to pay other forms of so-called 'educational costs', including 're-registration cost, school's development contribution, uniform fees, examination fees, etc.' (Coleman et al., 2004, p. 46). Hossain (2016) argues that 'rural schools mostly receive an education that is inferior compared to the students that live in the urban areas' (p. 2). Additionally, he mentioned other criteria that may contribute to the different achievements of students in English language learning in rural areas. Firstly, in terms of family factors, some experts believe that parents and relatives exert the biggest influence on young people's educational decisions (Esterman \& Hedlund, 1995; Israel et al., 2001), asserting that students in rural areas have low performance compared to students from urban areas due to the disparity of educational background of their parents (Israel et al., 2001). Secondly, financial factors might affect students' performance, as students from rural areas primarily come from families with a lowincome background. This can cause these students to have difficulties in finding adequate learning resources or enrolling in a more expensive higher-grade school when compared to students from urban areas. The last factor is that of educational logistic support. Most schools in rural areas still use a chalkboard/blackboard and do not have enough books to adequately support learning (Hossain, 2016). Another form of educational support is the availability of qualified and trained teachers in rural areas, as it was reported by the National Center for Education Statistics (1999) that the majority have had little or no PD before they teach English. Evidence such as that above indicates one particular shortcoming in the implementation of the Indonesian curriculum which is interpreted by Fullan (2007) as the failure of central government during the planning stage to take account of local context, situation and culture. 
In this regard, I believe that it is of paramount importance to investigate the actual application of each curriculum within the context of rural areas, specifically in the area of some opportunities and constraints that the curriculum possesses. So far, most of the literature discusses each curriculum - starting from the initial one established in 1945 until now - based on the policymakers' points of view, which might overlook critical features of why those curriculums constantly need change and improvement. The answer to this 'why' possibly could emerge from lower levels of curriculum executor such as teachers in rural areas. Therefore, I intend to explore the implementation of each curriculum in one of the rural areas in Indonesia by answering the following questions:

1. What are the English-curriculums that have been established in Indonesia?

2. What changes have been made to improve each curriculum?

3. What are the opportunities and constraints of these curriculums from the perspective of teachers in rural areas?

In order to address the disparity between the policymakers' intention in readjusting and improving the curriculum, and what actually happen in the implementation of these curriculum from the perspective of rural-area English teachers, this research tries to fill in the gap and provide the latest insights to the government as their additional considerations before deciding further policies in education. The remaining sections in this paper will then be added to orient the readers to my theoretical background, starting from the literature review which elaborates the educational system in Indonesia in general, and the latest curriculum applied. Method of research is discussed briefly afterwards, and findings and discussion, as well as the conclusion, are written in the last section of this paper.

\section{LITERATURE REVIEW}

\section{Educational System in Indonesia}

The Indonesian education system is organized by the Ministry of National Education and Cultures, widely known as Kemendikbud. Based on President Decree (2003) Number 20, The Ministry of Education and Culture has the responsibility to organise and control several programs relating to education and culture in Indonesia (Ristekdikti, 2016). Under Article VI of the decree (regarding Forms, Degrees and Types of Education), the government decides that the educational system in Indonesia should be organised by three levels of municipality, namely the central (Kemendikbud), provincial, and regional (or local) government.

As the government reformed the bureaucratic educational system in Indonesia (Ihsan, 2011) - commonly known as the 'reformation era' - in 2000 (Kamal, 2009), they started to decentralise the educational policy. Lamb and Coleman (2008) maintain that decentralisation in national education needs to be constructed upon the paradigm of regional autonomy. On one hand, this view supports the belief that each region and its local people are specialists in terms of their educational problems, and thus should be given the authority to manage their own educational system (Suryadi \& Budimansyah, 2004). On the other hand, however, the implementation of this decentralisation system does not intend to diminish the role and responsibility of central government. In this matter, 
Kemendikbud has the objective to produce fundamental strategic policies at a national level which act as a foundation for autonomous regions to establish their own policies.

In sum, the role of central government in managing the national educational system are as follows (adapted from Sahabat, 2014): 1) designing national and standard policies to control the quality of national education (Ristekdikti, 2016);2) designing minimum standards or national benchmarking for educational quality control in terms of educational facilities, human resources and the educational implementation processes; 3) controlling the flow of funds that come from various resources to be distributed to any educational institution in need through a system of subsidies; and 4) designing the national curriculum, including various elements of the curriculum itself, i.e. standard of minimum service, technical standards (management, funding, facilities, staff), standard of curriculum materials, assessment standards, teacher competencies standards, and academic achievement standards.

\section{Educational Decentralisation System}

Specific to the focus of this study into rural areas, the description of the educational system in Indonesia at a provincial and local level will be discussed briefly. With regard to the roles of each department, the provincial level is mandated to create and control every operational policy that is appropriate to local situations, developing and implementing programmes, and monitoring and arranging the provision of facilities to support education. One example of the role of the Provincial Education and Culture Department is in developing and conducting programmes such as the Professional Development (PD) of education personnel (Huda, 2016) to assist the implementation of the current curriculum in Indonesia (Curriculum 2013) (Sulfasyah et al., 2015). In this PD programme, teachers from across a regency in one province are selected based on their subject specification, and given curriculum training, in the hope that they will spread their understanding of how best to implement it (Burstein et al., 2014) to fellow teachers in their school. As the educational policy reaches the regional level, it is overseen by the government in Ministry regulation (2016) Number 24, article 1-5, which states that primary and secondary education units can develop a curriculum with a higher standard of Content Standards as set forth in Regulation of the Minister of National Education (Mendikbud, Peraturan Menteri Pendidikan Nasional Republik Indonesia Nomor 24 Tahun 2016, 2016). Here, local authorities - including school principals and teachers - have the discretion to develop the curriculum in the form of syllabuses and Rencana Pelaksanaan Pembelajaran (lesson plans) that are appropriate to their local context, or even higher in the level of attainment than what the government established in Attachment of the Regulations, Number 21, Year 2016. This development is constructed by referring to the guidance provided by BSNP (Badan Standar Nasional Pendidikan / National Education Standards Agency).

From the perspective of the central government's programme of decentralisation, this multi-level educational system in Indonesia is expected to be implemented across the country, including at a provincial and regional level. However, this intention has faced some obstacles in its application. First, the 
distribution of power to manage education at a regional level has led to dualism and controversies between regional and central agencies which are difficult to resolve (Huda, 2016). Second, the vast area that the central government had to cope with, coupled with inadequate distribution of information regarding the policy (i.e. the curriculum) across all areas in Indonesia (Puskurbuk, 2007) resulted in a timeconsuming process and uneven circulation of information.

\section{RESEARCH METHOD}

In order to address the research questions posed in the introduction section, this research employed a qualitative approach. Denscombe (2010) argues that the purpose of using the qualitative method is to provide a detailed and elaborate description to achieve an in-depth understanding of research participants or an issue of social/educational importance that is being investigated. As the main focus of this research was to analyse the English-curriculum change in Indonesia and to get a better insight of educational practitioners' - teachers, in this regard - perception towards this change, the qualitative approach was believed to be the most suitable method employed. Creswell (2014) remarks that this type of research method can combine multiple forms of data analysis, such as interviews, document analysis, and observation, instead of just relying on a single form of data. To support the methodology, I used historical and documentary research. According to Cohen et al. (2018), historical and documentary research in education could provide the targeted readers some insights into human social activity in relation to education. They contend that through this method, we could investigate what happened in the past, the progress of changing, and the starting point of what we see in the present.

In this matter, the data were obtained in the form of document analysis and semi-structured interviews. The document analysis was conducted first by investigating a number of works of literature in relation with curriculum, - or what Cohen et al. (2018) perceived as 'secondary documents' (p. 325) - selecting the essential issue, and addressing the relevant trend regarding the topic in question. A semi-structured interview was then employed to recall the teachers' experience in implementing the curriculum. Ary et al. (2009) describe semi-structured interviews as a way to elicit information from the interviewee in the way that they may not feel being intimidated during the process. The questions can be asked freely without any obligation to follow precisely the questions on the schedule. I asked four English teachers who have been teaching English in secondary schools for more than 20 years in one of the rural areas in West Borneo to be the informant. The selection used purposive sampling in order to specify the targeted informants in accord with the research purpose.

\section{FINDINGS}

\section{Curriculum Changes in Indonesia}

During the last fifty years, the Indonesian curriculum has undergone several periods of change in response to the evolution of worldwide teaching methodologies (Ahmad, 2014). Specific to ELT, the central government (since Indonesian Independence Day in 1945) obliged every school to include English as their teaching subject at junior and senior high level, replacing Dutch and Japanese, which were dominant during the colonial era (Jazadi, 2000). This decision was 
influenced by a number of key factors: (1) the decision to include the teaching of foreign languages was made early in 1950 as the political situation in Indonesia became more stable; (2) the former foreign languages (Dutch and Japanese) were viewed as the language of the colonialist; and (3) neither of these languages had international stature (Dardjowidjojo, 2000). Therefore, the government chose English as the compulsory foreign language to be taught in schools. However, this was also problematic in terms of the minimal resources that the government had at that time. To remedy this situation, the first Indonesian ambassador to the US - Ali Sastroamidjojo - approached the Institute of International Education and with a grant from the Ford Foundation, 'Indonesia began to embark on an In-Service English Teacher Training Project in October 1953' (Dardjowidjojo, 2000, p. 24). Later in the process, the English education curriculum in Indonesia followed current developments in ELT around the globe. Such developments and changes will be elaborated upon briefly, accompanied by a timeline for curricular change (table 1).

\section{Grammar-Translation Based Curriculum}

At the beginning of its implementation, the goal of teaching English was to support students to read literature in English, become involved in classroom discussion, and complete an examination. During that period of time, the intention for ELT in Indonesia was dedicated to support tertiary level students in academic fields. In 1945, in the aftermath of independence, ELT in Indonesia focused on the Grammar Translation Approach (GTA). Sahiruddin (2013) further suggested that GTA was chosen as the best approach since it only required these local teachers to master the grammatical elements of the language. This approach was also relatively inexpensive in terms of financial support, and suitable for classrooms where English was taught to more than twenty students. However, this approach focused more on translating literature due to a shortage of literature for students to read in Bahasa during this time, resulting in a lack of practicing the language itself. Therefore, the government tried to remedy the situation by giving more emphasis on the use of the language through the changing of the curriculum within the next five years.

\section{Audiolingual-Based Curriculum}

In the early 1950s, the audio-lingual approach (audiolingualism) was then introduced (Sahiruddin, 2013). It emphasises oral activity through memorisation and mimicry (Celce-Murcia et al., 1995). This approach developed as a counterreaction towards previous approaches which lacked emphasis on oral-aural skills. In this curriculum, further technology-based materials were the main features (i.e. language labs and audio cassette accompanying textbooks). There were, nevertheless, as many obstacles to apply this curriculum as the improvement of the previous one. For instance, large class numbers meant that most teachers continued to use the grammar-translation method. As for the schools situated outside of Java island, such privilege of language labs was still a notion of being realized.

\section{Revised Audiolingual-Based Curriculum}

Because of this problem, in 1975 the government reformed and revised the curriculum, but still under the audiolingual framework. Improvements were made in terms of providing teachers with systematic guidelines that included learning 
objectives, teaching materials, teaching procedures, and how to evaluate the learning progress (Tjokrosujoso \& Fachrurrazy, 1997).

Table 1. English-Curriculum change in Indonesia

\begin{tabular}{rll}
\hline No & \multicolumn{1}{c}{ Year } & \multicolumn{1}{c}{ Curriculum } \\
\hline 1 & 1945 & Grammar translation-based curriculum \\
2 & 1958 & Audiolingual-based curriculum \\
3 & 1975 & Revised audiolingual-based curriculum \\
4 & 1984 & Structure-based communicative curriculum \\
5 & 1994 & Meaning-based communicative curriculum \\
6 & 2004 & Competency-based curriculum \\
\hline 7 & 2006 & School-based curriculum \\
\hline 8 & 2013 & Curriculum 2013 (K-13) \\
\hline
\end{tabular}

Sahiruddin (2013) concludes that the implementation of the curriculum, however, remained problematic. After several years, there was a tendency for teachers to ignore the principles of the audiolingual-based curriculum, mainly due to the fact that some fundamental elements of the audiolingual approach (such as having native speaking English teachers and using language laboratory equipment) were absent in the actual teaching-learning process.

\section{Structure-Based Communicative Curriculum}

Dissatisfaction toward the audiolingual-based curriculum led the Ministry of Education to promote the communicative approach curriculum in 1984. The main objective of this curriculum was to help students develop their ability to use English for communicative purposes including four macro skills: reading, listening, speaking and writing (Musthafa, 2001; Sahiruddin, 2013). Yet, as analysis of the official textbooks produced by the Department of Education demonstrate, grammatical structure was still the main focus of teaching activity and dominated the books' content. By referring to the theory of Communicative Competence proposed by Celce-Murcia et al. (1995) - including linguistic, strategic, sociocultural, actional, and discourse competence - this communicative approach curriculum tended to prioritise linguistic competence in English over the other competences in its implementation. Such disproportion among competences could lead students to only partially master the English language.

\section{Meaning-Based Communicative Curriculum}

Subsequent to the unsuccessful implementation of the 1984 curriculum, the government applied a meaning-focused communicative curriculum in 1994. Again, this was also based on the principles of the communicative approach, but with some modifications, namely that it tried to minimise the influence of forms-focus, or the grammatical aspect (Dardjowidjojo, 2000). In this curriculum, the government more strongly emphasised the 'meaningfulness' or 'kebermaknaan' of the communicative approach through engaging themes in the course book (Jazadi, 2000) designed to stimulate classroom discussion. The government then focused this new curriculum to develop students' ability to master the four skills of English (listening, reading, speaking and writing), all of which were equally promoted. However, Sahiruddin (2013) believed that teachers prioritised reading over the other three skills, and the national examination still assessed students' reading comprehension as well as their grammar through multiple-choice format. 


\section{Competency-Based Curriculum}

In 2004, the competency-based curriculum or Kurikulum Berbasis Kompetensi (KBK) was established as a reflection upon and improvement of the 1994 curriculum. Within the same basic theoretical framework as the previous curriculum (communicative competence), KBK focused more on helping the learner attain the specific knowledge and skills needed for communication (Watson, 1990). In conjunction with this statement, Marcellino (2008) contends that this type of curriculum can be both functional and interactional, in that it provides the learners with social contexts to help them relate learnt competence to situations where it can be used for communicative purposes. In specific to rural areas, this type of learning which based on contextuality could benefited both teachers and learners due to lack of learners' interest in learning and limited learning materials. Hence, providing appropriate context could trigger their engagement in learning. One of the teachers whom I interviewed remarked:

T1: It was easier for me to teach them (students) since the book provided a context for each activity, such as speaking and writing. Again, it was just easier for me to teach them, but how they understand the material is different case.

Another teacher similarly commented:

T3: Although the book from the government was late, but the guidance from the book make the students find it interesting because the book has a lot of informal activities as exercise. The indicators for each activity was also clear, so I can observe whether they have achieved the minimum requirements or not.

Despite its strengths, this curriculum displayed some shortcomings, one of which was the assessment of competencies within national examinations. Which methodologies best measure learners' performance (i.e. test, portfolio, ratings by the teacher, etc.) is still a matter of debate. Another aspect is that, as Nadolski et al. (2001) suggest, KBK needs to provide learners with authentic tasks, whereas Marcellino (2008) believes that most teachers in Indonesia are still far from ready to meet this expectation. In this matter, teachers added:

T1: They (the government) told us to give authentic assignments to students that suit local values. However, by the end of the learning process, they require my students to take the national exam, which-obviously-doesn't have any local content. Isn't it pitiful?

T4: Even we as the teacher don't know much about KBK to be honest. We didn't get much information, and not to say any training from the government.

\section{School-Based Curriculum}

Not long after that, further improvements were made by the Indonesian Department of Education to enhance the teaching and learning processes. Within just two years of KBK's introduction, in 2006, the government announced that the new curriculum - the school-based competence or Kurikulum Tingkat Satuan Pendidikan (KTSP) curriculum - would be implemented as an educational framework across the nation (Sulfasyah et al., 2015). Muslich (2007) explains that under the KTSP, schools were allowed to develop their own school-based syllabus 
by referring to the standard competencies and standard content as outlined in the main curriculum.

T2: I believe, KTSP was established only two years after KBK simply because the government finally recognise the importance of local contents in learning instead of forcing the national standard to rural areas like us.

This was to ensure that every student in Indonesia could meet the minimum standards set by the government, while schools could establish learning programmes matching their local context. However, it was felt that the KTSP had several crucial problems that needed to be addressed.

T2: We were still adapting to use the KBK, even after two years of its implementation, we didn't know much about. Then all of a sudden, they (the government) change it again. What on earth were they thinking?

T4: We were struggling to catch up with the changing. Not only for us, students were required to buy this book and that book when the curriculum changed. I was so frustrated. I prefer to teach everything the old-fashion way. Explain the material, ask the students to do some assignments, then give them homework.

One particular study assessing the implementation of the KTSP curriculum found the most apparent issues were the following: the KTSP forced students to learn subjects beyond their limits, the teacher-oriented approach was still applied in the teaching-learning process, and, as the implementation of National Examination only assessed reading and listening, teachers were led to spend disproportionate time teaching these strategies, yet neglecting to provide the opportunity for students to practice the use of English in the classroom (Putra, 2014). Therefore, in line with this argument, the Indonesian government decided to reformulate the KTSP curriculum into the current 2013 version.

\section{Implications of the new Curriculum 2013}

Since the 15th of July 2013, the Indonesian curriculum, called Kurikulum 2013 / Curriculum 2013 (hereafter K-13), has been implemented as a platform for the teaching-learning process. Compared to its predecessor, K-13 put more emphasis on building students' characters, developing skills relevant to their needs and interests, and using a theme-based learning approach to develop students' cognitive abilities. In this sense, the government uses K-13 as a platform for students to gain better understanding of their lessons through accessing various learning resources, such as books, the internet, social contexts, etc. with the teacher's role as that of facilitator guiding them to obtain the learning target (Seran, 2014).

In relation to English, Putra (2014) states that K-13 made some significant adjustments to the content, which are as follows: 1) the number of teaching hours in senior-secondary schools has been reduced; 2) content of the teaching materials has been reduced; 3) topics for discussion have been limited; 4) grammatical content has been added explicitly; 5) emphasis placed on the integration of listening, reading, speaking and writing; 6) reduction of teachers' workloads in developing learning materials. 
At senior-secondary school level, the purpose of studying the English subject within K-13 is to develop the pupils' competence in: (1) identifying the social function of oral and written text structure in their daily life activity; (2) using interpersonal, transactional and functional communication; (3) arranging and editing oral and written text in order to be accurate and meaningful; and (4) using language properties spontaneously and accurately (Mendikbud, Peraturan Menteri Pendidikan dan Kebudayaan Nomor 21 Tahun 2016 Tentang Standar Isi Pendidikan Dasar dan Menengah, 2016). Putra (2014) contends that these goals might imply that there is a correlation between the basic theory of the development of this curriculum with the intention of the policymakers. This theory is proposed by Wells (1987) as the language literacy model. In his theory, Wells divides literacy into four levels, namely performative, functional, informational and epistemic. Further to this division, in the guidelines of K-13 (Mendikbud, 2013; Mendikbud, 2016) it is stated that students in junior-secondary school (grades 7-9) are expected to reach the literacy level of functional, meaning students have the ability to use English for various purposes e.g. reading brochures or English magazines. Similarly, senior-secondary school students (grades 10-12) are expected to acquire an informational level of literacy, at which they are able to access any information in English. In regard to this situation, one teacher stated:

T3: True. That is the ideal goal. But let's try to think for a moment. In this region, how often do you think students will encounter English magazine? If, and only if so, I don't think they'd like to read it. We don't have the privilege here, not every student here has a smartphone.

Of all the outwardly positive objectives this K-13 aims to achieve, there have, however, been several criticisms from experts regarding its implementation. Ahmad (2014) explicates that there are inefficiencies and an unequal distribution of information about K-13 across the different regions in Indonesia. Seran (2014) in his review of K-13 asserts that some major factors contributing to the disparity among regions in Indonesia include their infrastructures, topography and the centralised focus of the distribution of K-13 only in Java island, where the capital city of Indonesia is located. As a result, some teachers - especially those in rural areas - tend to believe that the learning process is the actual process as outlined in the curriculum and syllabus, with little or no effort made to critically adjust the materials to the context of students' environment and culture (Ahmad, 2014).

T1: We (the teachers) live here, far from home. Some of us even came from Java island. The disparity is evident between system there and in here. The K-13 was established in 2013 but we still haven't got the training about it until 2016. I do hope that the issue of capital city move to Kalimantan will actually come true and there will be some improvements in education especially to rural areas like us here.

By considering the third previously outlined adjustment and the action taken by the teachers, learners might be easily demotivated and lose interest from being exposed to the same materials repeatedly for one semester. The second impact that teachers also have a tendency to use only those learning materials provided by the government (i.e. textbooks) to teach English (Ahmad, 2014) - may lead to the 
passiveness of classroom activity, due to student disengagement, likely provoked by the book-oriented approach adopted by the teacher. Finally, as Segovia and Hardison (2009) show in their study, with the change of curriculum, classroom teachers tend to use their old practices instead of adopting those the government promotes. Similarly, it was found that the learner-centred approach did not exist in the classroom environment as demanded by the curriculum (Blignaut, 2008). In sum, the problems that are presented above actually occur throughout the nation, and will likely require considerable input from higher stakeholders, teachers, language instructors, scholars, experts and others to address those problems carefully.

\section{CONCLUSION}

In general, there seemed to be an overall agreement among teachers that students' low motivation to learn English is the biggest obstacle they face in teaching them. Most of them remarked that such a situation might relate to the fact that: firstly, English is not their mother tongue; secondly, the students have an insufficient English vocabulary; and finally, they simply learn the English subject because it is compulsory, and only to get a mark and pass their exams. They also feel that students in a rural area did not get enough exposure to or opportunities to express themselves in English. One teacher underlined the differences between rural area and big cities, arguing that in big cities, there are many events that provide the opportunity for students to use English, not only related to the academic but also to other fields.

Finally, the inadequate facilities to support learning are also a significant problematic factor for those teaching students in rural areas. These facilities are not only limited to technological resources, but also to more standard learning resources, such as textbooks and student worksheets. This fact gives further evidence similar to the situation described above - where the distribution of K-13, as well as other curriculum predecessors (which also includes the government textbooks) has not reached all levels of education in rural areas. It also proves Seran's (2014) claim regarding the centralisation of K-13 distribution as only fullyrealised in Java island (as it is the capital city of Indonesia), resulting in the unequal distribution across other regions, and, particularly, rural areas.

It appears that despite the changes and improvements toward the curriculum, the governments failed to acknowledge the difficulties in rural areas. Having said that, acknowledging is not something that will be sufficient in solving the problems. Even though the government managed to notice them, dealing with the issues would require another level of effort and determination. Such remarks from the teachers in this research should be giving the stakeholders insights and consideration, if needed, to restructuring and reforming the curriculum for the betterment of future education.

\section{REFERENCES}

Ahmad, D. (2014). Understanding the 2013 curriculum of English teaching through the teachers' and policymakers' perspectives. International Journal of Enhanced Research in Educational Development (IJERED), 2(4), 6-15. 
Ary, D., Jacobs, L. C., \& Sorensen, C. (2009). Introduction to research in education $\left(8^{\text {th }}\right.$ ed.). London: Cengage Learning [distributor].

Baso, R. S. (2014). Exploring Indonesian graduates' English language skills and companies' English language skills requirements in East Kalimantan, Indonesia. IOSR Journal of Humanities and Social Science, 19(6), 44-56.

Bjork, C. (2004). Decentralisation in education, institutional culture and teacher autonomy in Indonesia. International Review of Education, 50(3/4), 245262.

Blignaut, S. (2008). Teachers' sense-making and enactment of curriculum policy. Journal of Education, 43(1), 101-125.

Burstein, J., Shore, J., Sabatini, J., Moulder, B., Lentini, J., Biggers, K., \& Holtzman, S. (2014). From teacher professional development to the classroom: How NLP technology can enhance teachers' linguistic awareness to support curriculum development for English language learners. Journal of Educational Computing Research, 51(1), 119-144.

Celce-Murcia, M., Dornyei, Z., \& Thurrell, S. (1995). Communicative competence: A pedagogically motivated framework with content specifications. Issues in Applied Linguistics, 6(2), 5-35.

Cohen, L., Manion, L., \& Morrison, K. (2018). Research methods in education ( $8^{\text {th }}$ ed.). New York: Routledge.

Coleman, H., Asoko, H., Azhar, F., Holloway, K., Lamb, M., Sagimin, \& Wedell, M. (2004). Survey of education in Riau 2003-2004. Leeds: University of Leeds.

Creswell, J. W. (2014). Research design: Qualitative, quantitative, and mixed methods approaches $\left(4^{\text {th }} \mathrm{ed}\right.$.). London: SAGE Publications.

Dardjowidjojo, S. (2000). English teaching in Indonesia. English Australia Journal, $18(1), 22-30$.

Denscombe, M. (2010). The good research guide: for small-scale social research projects $\left(4^{\text {th }} e d.\right)$. New York: McGraw-Hill Open University Press.

Esterman, K., \& Hedlund, D. (1995). Comparing rural adolescents from farm and nonfarm families. Journal of Research in Rural Education, 2, 1-24.

Fullan, M. (2007). The new meaning of educational change (4 ${ }^{\text {th }}$ ed.). London: Routledge.

Hossain, M. (2016). English language teaching in rural areas: A scenario and problems and prospects in context of Bangladesh. Advances in Language and Literary Studies, 7(3), 1-12.

Huda, N. (2016). Decentralization of education in Indonesia: Problems of implementation. Jurnal Ilmu Pendidikan, 5, 3-12. 
Ihsan, H. F. (2011). Dasar-dasar kependidikan (7th ed.). Indonesia: Rineka Cipta.

Israel, G. D., Beaulieu, L. J., \& Hartless, G. (2001). The influence of family and community social capital on educational achievement. Rural Sociology, 66(1), 43-68.

Jazadi, I. (2000). Constraints and resources for applying communicative approach in Indonesia. EA Journal, 8(1), 31-40.

Kamal, S. (2009). The history of English curriculum in Indonesia. Retrieved from https://paksira.wordpress.com/2009/05/22/the-history-of-englishcurriculum-in-indonesia/

Lamb, M., \& Coleman, H. (2008). Literacy in English and the transformation of self and society in Post-Soeharto Indonesia. International Journal of Bilingual Education and Bilingualism, 11(2), 189-205.

Marcellino, M. (2008). English language teaching in Indonesia: A continuous challenge in education and cultural diversity. TEFLIN Journal, 19(1), 5769.

Mendikbud, M. P. (2016). Peraturan menteri pendidikan dan kebudayaan nomor 21 tahun 2016 tentang standar isi pendidikan dasar dan menengah. Jakarta: Ministry of Education and Cultures.

Mendikbud, M. P. (2016). Peraturan menteri pendidikan nasional republik indonesia nomor 24 tahun 2016. Jakarta: Mendikbud.

Muslich, M. (2007). KTSP: Pembelajaran berbasis kompetensi dan kontekstual: panduan bagi guru, kepala sekolah, dan pengawas sekolah. Jakarta: Bumi Aksara.

Musthafa, B. (2001). Communicative language teaching in Indonesia. Journal of Southeast Asian Education, 2(2), 1-10.

Nadolski, R. J., Kirschner, P. A., Merriënboer, J. J., \& Hummel, H. G. (2001). A model for optimizing step size of learning tasks in competency-based multimedia practical. Educational Technology Research and Development, 49(3), 87-103.

National Center for Education Statistics. (1999). Teacher quality: A report on the preparation and qualifications of public school teachers. Washington: U.S. Department of Education, Office of Educational Research and Improvement.

Nunan, D. (2003). The impact of English as a global language on educational policies and practices in the Asia-Pacific region. TESOL Quarterly, 37(4), 589-613.

Puskurbuk, P. K. (2007). Laporan hasil pemantauan pelaksanaan Standar Isi dan Standar Kompetensi kelulusan [A report on monitoring findings on the implementation of Content Standard and Graduate Competency Standard]. 
Jakarta: Badan Penelitian dan Pengembangan, Depdiknas [Research and Development Board, Department of National Education].

Putra, K. A. (2014). The implication of curriculum renewal on ELT in Indonesia. Parole: Journal of Linguistics and Education, 4(1), 63-75.

Ristekdikti. (2016). Sindikker (Sistem Informasi Pendidikan dan Dunia Kerja). Retrieved from http://sindikker.dikti.go.id/dok/UU/UU20-2003Sisdiknas.pdf

Sahabat, W. (2014). Contoh makalah pengelolaan sistem pendidikan nasional. Retrieved from http://www.warna-sahabat.com/2014/05/contoh-makalahpengelolaan-sistem.html

Sahiruddin. (2013). The implementation of the 2013 curriculum and the issues of English language teaching and learning in Indonesia. The International Academic Forum, 567-574.

Segovia, L. P., \& Hardison, D. M. (2009). Implementing education reform: EFL teachers' perspectives. ELT Journal, 63(2), 154-162.

Seran, W. H. (2014). Kurikulum 2013 kontekstual dalam pengembangan, namun tidak dalam terapan. from http://www.kompasiana.com/wellyseran/kurikulum-2013-kontekstualdalam-pengembangan-namun-tidak-dalamterapan_54f5efd2a33311f0018b45ef

Sulfasyah, Haig, Y., \& Barratt-Pugh, C. (2015). Indonesian teachers' implementation of new curriculum initiatives in relation to teaching writing in lower primary school. International Journal of Education, 7(4), 53-72.

Suryadi, A., \& Budimansyah, D. (2004). Pendidikan Nasional Menuju Masyarakat Indonesia Baru. Bandung: Genesindo.

Tjokrosujoso, H., \& Fachrurrazy. (1997). Pengembangan materi bahasa Inggris dan kurikulum SMU. Jakarta: Universitas Terbuka.

Watson, A. (1990). Competency-based vocational education and self-paced learning. monograph series. Sydney: Technology University.

Wells, G. (1987). The meaning makers: children learning language and using language to learn. London: Hodder and Stoughton Educational. 